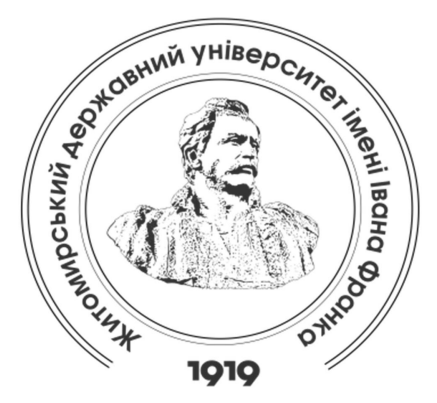

Zhytomyr Ivan Franko State University Journal. Pedagogical Sciences. Vol. 1 (104)

Вісник Житомирського державного університету імені Івана Франка.

Педагогічні науки. Вип. 1 (104)

ISSN (Print): 2663-6387

ISSN (Online): 2664-0155

\author{
UDC 378.147:37.091.33:004.5 \\ DOI 10.35433/pedagogy.1(104).2021.40-49
}

\title{
INFORMAL EDUCATION AS AN EFFECTIVE FORM OF DEVELOPMENT OF PROFESSIONAL COMPETENCE OF MODERN COMPUTER SCIENCE TEACHER
}

\section{O. A. Tokarska*}

In modern conditions formal education is unable to meet the various educational needs of teachers, especially when it comes to ICTs and computer science (CS), so informal adult education is becoming an increasingly urgent personal need of modern educators. Taking into consideration the challenges of today and the demands to the teachers, the state has provided for the possibility of continuous teacher training in the new Law on Education. Despite the fact that the issue of professional development of educators was given considerable attention in the researches of community, the problem of professional competence of modern CS teachers in the field of informal education remained insufficiently covered and was not the subject of a dedicated special research. The aim of the article is to outline the optimal ways to develop the professional competence of computer science teachers in the system of informal education. Theoretical research methods were used during research, namely: study and analysis of psychologicalpedagogical, normative and special literature on the above-mentioned issue(s); analysis of state educational standards, programs, textbooks and teaching materials. Some its aspects are defined and the ways of organizing the process of development of professional competence of teachers in the conditions of informal education are described. It is determined that further research is aimed at processing and testing the research-based materials in real conditions. The analysis of the legal framework in the field of education showed that the state is currently taking a number of measures to ensure the continuous development of professional competence of modern CS teachers as well as the development of professional competence of modern educators in general, which should include such areas that will allow teachers to exploit new approaches and educational technology that can improve and amplify the learning process of students.

Key words: education, informal education, development, professional competence, computer science teacher, development of the professional competence of a modern teacher.

\footnotetext{
${ }^{*}$ Computer Science teacher

(Ozerne gymnasium)

tokao@ukr.net

ORCID: 0000-0002-8761-8182
} 


\section{НЕФОРМАИЬНА ОСВІТА ЯК ЕФЕКТИВНА ФОРМА РОЗВИТКУ ПРОФЕСІЙНОÏ КОМПЕТЕНТНОСТІ СУЧАСНОГО ВЧИТЕАЯ IНФОРМАТИКИ}

\section{О. А. Токарська}

У сучасних умовах формальна освіта неспроможна задовольнити різноманітні освітні запити вчителів, особливо тодi, коли ие стосується інформаційно-комунікаційних технологій та інформатики, тому неформальна та інформальна освіта дорослих стає все більш нагальною особистісною потребою сучасного вчителя. Врахувавши виклики съогодення та потреби педагогів, держава передбачила можливість безперервного навчання вчителів у новому Законі про освіту. Незважаючи на те, шо питанню розвитку професіоналізму вчителя приділялася значна увага у дослідженнях наукової спільноти, проблема розвитку профресійної компетентності сучасного вчителя інформатики в умовах саме неформальної освіти залишалася практично поза їх увагою $i$ не була предметом спеціального наукового дослідження. Мета статті полягає в окресленні оптимальних шляхів розвитку професійної компетентності вчителів інформатики в системі неформальної освіти. У роботі використовувалися теоретичні методи дослідження: вивчення та аналіз психолого-педагогічної, нормативної та спеиіальної літератури з проблеми дослідження; аналіз державних освітніх стандартів, програм, навчальних посібників і методичних матеріалів. Визначено окремі аспекти та описано шляхи організаиї процесу розвитку професійної компетентності вчителів в умовах неформальної освіти. Визначено, шо подальші пошуки спрямовані на опрацювання та апробацію матеріалів наукового дослідження в реальних умовах. Проведений аналіз законодавчої бази в галузі освіти показав, що нині державою здійснюється низка заходів шодо забезпечення безперервного розвитку професійної компетентності сучасного вчителя, розвиток професійної компетентності сучасного вчителя має включати такі напрямки, які дадуть можливість педагогу застосовувати нові підходи до формування освітнъого середовища і використання новітніх технологій у проиесі навчання учнів.

Ключові слова: освіта, неформальна освіта, розвиток, професійна компетентність, вчитель інформатики, розвиток професійної компетентності вчителя.

Introduction of the issue. The relevance of the research topic is due to the global process of informatization of society, the basis of which is the informatization and digitalization of education, which should precede the application of ITCs to other areas of social activity, for education serves as the basis of social, cultural and professional prerequisite for informatization of society.

According to the Concept of National Informatization Program [10] and the Concept of Development of Digital Competences up to 2025 [12], informatization and digitalization of education is aimed at forming and developing the intellectual potential of the nation, improving the forms and content of the educational process, introducing computerized methods of teaching and testing, providing opportunities for lifelong continuous learning, as well as providing comfort in a digital country, increasing access to public services, reducing risks and dangers of Internet use in different spheres of life. The results of informatization of education should be the following: computer-based (computerized) education; development of the content of teaching methods and tools to the level of world-acknowledged standards; integration of educational activities and application of informatization of Ukraine through specialization and intensification of training of relevant specialists.

In such conditions, the system of education faces one of the most important tasks, which implies preparation of students for living 
conditions in the modern information society. The growing need for information, technology and visual literacy of school leavers, understanding that students have changed and educational practice still remains the same, for it requires a significant number of teachers who have practical ICT-skills, which are identified by international educational communities and organizations [5]. All this concerns the professional competence of modern educators, computer science teachers in particular, who must first master and possess corresponding knowledge and relevant skills. The problem of developing the professional competence of CS teachers in the system of informal education becomes urgent.

Current state of the issue. Issues of development of professional pedagogical competence of teachers are considered attention in the works of many scientists (S. Sysoieva [15], N. Balovsiak [1], O. Kozyrina [7], O. Kryvosheieva [8], O. Ovcharuk [9], A. Khutorskyi [16], A. Shyshko [17] and other).

The outline of unresolved issues brought up in the article. In recent years a number of works covering the ways of formation and development of professional competence of teachers in the context of formal education has been published, thus reviewing educators of different specialties, namely: Ukrainian language and literature $[3 ; 6]$; teachers of environmental disciplines [2;3]; future teachers of computer science [14]; active CS teachers [5]. However, not enough attention is paid to the development of professional competence of modern computer science teachers in the field of informal education.

Aim of research. Thus, taking into consideration the urgency of the issue studied and lack of solution to the problem of modern CS teachers' professional competence development, the aim of the article is to outline the optimal ways to build up the professional competence of computer science teachers in the system of informal education.

Results and discussion. In modern conditions formal education is unable to meet the various educational needs of educators, especially when it comes to ICTs and computer science, so undergoing corresponding informal adult education is becoming an increasingly urgent mandatory requirement to a modern teacher. Considering current state of things and needs of teachers, the state has provided for the possibility of continuous teacher education in the new Law on Education, according to which educators have the opportunity to choose one particular type of lifelong continuous learning, namely: formal and informal.

Many researchers identify concept of "education" as an organized and long process of learning in preschool, primary, secondary school, undergoing vocational training, therefore, representing it in a form of a strictly hierarchical system, which currently requires significant adaptation of knowledge transfer technologies to the modern needs of the society, namely digitalization of the means of communications, emergence of ICTs, ELearning, M-Learning, etc.

UNESCO experts have defined the term "E-Learning" as "learning through multimedia and the Internet", thus it is in high demand among different consumer groups, namely: corporate (training and education of employees, in particular, self-education); educational (state and/or non-state (commercial) educational institutions that provide educational services (ES)); individual (individual E-Learning users and corresponding content consumers: primarily users of the Internet, educational portals, wiki resources and other ES in the network).

The spread and availability of mobile devices (PDAs, tablets and 
smartphones) have led to the development of a new direction of $\mathrm{E}$ learning - Mobile Learning (MLearning). M-Learning involves the use of mobile communication tools in the learning process, i.e. all educational content is downloaded to a mobile device and thus the process of acquiring knowledge is no longer limited by space and time, as almost any modern smartphone has access to the Internet. Therefore, an educator can give lectures, study materials, complete tasks, give tests, communicate with colleagues and get an assessment of students' knowledge in real time.

The European system of education has been using the concept of "Lifelong Learning" for a long time in its Strategy for the Development of Training and Retraining, Adult Education Section [UNESCO]. Thus, the major peculiarity of such an approach is that continuing education lifelong is a basic principle of the entire European staff qualification system and not just one of the retraining models. Lifelong learning (LL) in the European Union is considered one of the main structural components of society. The UNESCO International Commission on Education for the 21st Century has formulated the essence of this approach as follows: learn to cognize; learn to do; learn to live together; learn to live. In this regard, western scholars, researchers and experts have discussed the need to change existing paradigms in the educational systems in the late twentieth century, which led to the development of "adult education" concept. Considerable attention was paid to informal education, development of various forms of selfeducation and unconventional education.

36th session of UNESCO (held in Paris, 2011) summarized current issues of the existing educational systems and offered the new revised international standards for the classification of education in a resolution. According to it, education becomes informal in the case of being purposeful and planned by a person or organization that provides educational services [19]. Thus, this year was a turning point for informal learning, as it was recognized not as a mere supplement, but a possible alternative to formal education in lifelong learning. The main problem is the availability and provision of universal access to such programs. Informal education has no age restrictions, can be short in duration and low in intensity.

Theoretical research of the abovementioned problem at the national and world-wide levels, as well as practical experience allow us to state that modern postgraduate education in Ukraine requires profound systemic changes, in particular: focusing the attention of the heads of public administration and local government on the role of education at all levels (formal, unconventional, informal) in the modernization of the education system in Ukraine; attracting attention to the individualization of the process of improving professional competence and training; introduction of new ways and algorithm of improvement, development of professional competence of a teacher in the conditions of informal education; development of distance education and distance learning system; improving the competence and strengthening the responsibility of state officials involved in professional development of the teachers.

According to the Draft of the New Law on Postgraduate Pedagogical Education and the Law of Ukraine "On Education", informal education is defined as that obtained through educational programs and does not provide for the award of staterecognized educational qualifications by level of education, but may end with professional and/or partial educational qualifications.

[https://www.naiau.kiev.ua/news/obg ovorennya-proektu-zakonu- 
ukrayini.html]. Thus, informal education as an integral part of the continuous professional development of a specialist, as well as the developmental tool of improving pedagogical skills of a computer science teacher, promoted the emergence of many opportunities for teacher training, including the following areas: scientific and pedagogical, practiceoriented, creative and developmental, etc. The inclusion of computer science teachers in face-to-face and distance participation in scientific and pedagogical activities provides many benefits, including the formation of scientific thinking, vision of prospects for professional development and improvement of pedagogical skills, exchange of experience and interaction among professionals based on discussion of pedagogical problems, introduction of innovations in educational practice. Among the important forms of informal education of teachers are scientific and practical conferences, seminars, webinars, online conferences and various types of distance and mixed learning of teachers.

Among the main aspects of the choice of content and forms of development of professional competence of computer science teachers due to modern educational and social requirements are: elaboration of legislative and regulatory documents on education; study, development of new scientific ideas of digital education; study of perspective pedagogical experience.

The content component of the process of development of professional competence of CS teachers includes: systematic study of psychologicalpedagogical and scientific literature selected in accordance to the particular subject area; direct participation in the school life; taking part in interschool and district/regional methodological associations, seminars, conferences, etc.; search for ways to improve own pedagogical skills; conducting experimental research; abstracting and implication of pedagogical and methodical journals, article collections, etc.; maintaining author's scientific publishing activity.

The organizational component of the process of development of professional competence of computer science teachers in the system of informal education provides: current and future planning; selection of rational forms and means of assimilation and storage of information; mastering the methods of analysis and generalization of own and collective experience; gradual development of methods of research and experimental activities. In the course of research, the approximate plan of the organization of process of development of professional competence of the modern CS teacher in the conditions of informal education was designed, which consists of six stages, which are realized during the course and intercourse periods of training. The experience of practical activity makes it possible to determine the main pedagogical conditions that can most effectively influence the process of development of professional competence of computer science teachers in the system of informal education:

1) guiding computer science teachers towards professional growth and development, improvement (including self-improvement) of their professional competence, increasing the efficiency of his/her pedagogical activity;

2) applying innovations (electronic educational resources, including electronic textbooks, etc.) to primary school teaching (CS), as well as implementing interactive pedagogical technology in order to the develop professional competence of computer science teachers within seminars on annotated instructional and methodological recommendations.

We suggest considering application of innovations and interactive 
pedagogical technology of development of CS teachers' professional competence within the framework of school regional seminars in the forms that provide:

1) implementation of a comprehensive approach to the development of professional competence of CS teachers in the system of informal education based on the introduction of productive active (interactive, based on information and communication) learning technologies in the system of education and the process of professional competence development, including cloud technologies, developmental learning technologies, project technology, etc.;

2) optimal combination of forms of organization of educational process and designing of active and interactive methods of moderating training at seminars of different levels: round-table talks, debates of IT specialists, presentation of own creative projects, etc.

Interactive educational technologies aimed at developing professional competence of CS teachers allow the transformation of educational activities into professional ones, implementing the basic provisions of the competence approach to goal setting, organization of the process of professional competence development and evaluation of its results. Thus, it is identified as a pedagogical tool that gives a possibility to implement methodological, didactic goals that are transformed into a targeted program (set) of action.

According to K. Hicks, the methodological subsystem of general secondary education must be constantly evolving due to the emergence of new technologies all over the world: the introduction of innovations, new approaches to the educational process, the use of cloud and mobile technologies, the application of new electronic educational resources, availability of access to open educational content, monitoring and educational analysis of learning environment [20].

In the era of informatization of society, the use of innovative technologies in the field of education is becoming a necessary prerequisite for the development of professional competence of modern teachers and the younger generation. The main activities of a modern CS educator, taking into consideration wide use of innovative technologies in the development of professional competence, are the following:

$>$ evaluation of the requirements for the formation of the educational environment, including digital one;

$>$ mastering the organizational forms of using the multimedia tools and means complex to work with the students in class;

$>$ awareness of the aim, content and feasibility of using electronic educational resources;

$>$ creation of organizational and pedagogical conditions and forms of technology implementation in GSEI (general secondary education institution);

$>$ introduction into pedagogical practice of innovative methods of teaching students with the use of ICTs;

$>$ mastering and applying organizational and methodological aspects of lesson development using a digital textbook (e-textbook);

understanding the functionality, methods and ways of using technology in the educational process;

$>$ skillful combination of traditional and computerized methods of organizing and monitoring the level of students; achievement;

$>$ organization of the lesson and evaluation of its effectiveness with the use of innovative technologies (digital textbook (e-textbook), computer testing, online educational resources, etc.).

Therefore, the above-mentioned aspects should be included in the plans for seminars (in-school and extracurricular formats) on the 
organization of the process of developing the professional competence of teachers in the conditions of informal education. Thus, we have offered a way of developing the professional competence of a modern educator, in particular a computer science teacher, in the context of informal education, which includes the following basic concepts: electronic educational resource(s) (EERs); educational internet resource(s) (EIRs); electronic learning tool(s) (ELTs); online resource; webinar; online conference; cloud services.

Let's consider some online resources that can be used by a computer science teacher in the development of his/her professional competencies while undergoing informal education.

EdEra - the studio of online education, which offers two main options: free courses for everyone (from students to lawyers, from teachers to economists) and the creation of complete ready-to-use projects to train employees of a particular organization (for corporate customers). Therefore, this online platform contains approximately $80 \%$ of free projects; the remaining $20 \%$ - corporate orders and business clients; there are 66 major projects to choose from: online courses, interactive lessons, interactive textbooks.

EdEra Books - the project of interactive educational literature. EdEra's online books consist of illustrated texts with integrated videos and tests to assess the readers' knowledge. Moreover, the platform allows to combine different methods of information perception and increase the effectiveness of learning. For computer science teachers, as well as major subject teachers, the online resource offers free refresher (retrain) courses with round-the-clock and full online access. Filling a short registration form is a prerequisite for accessing the available materials.

Cisco Network Academy - a powerful resource for the development of professional competence of a modern computer science teacher in a form of a program that combines the power of technology and modern teaching methods. By opening new opportunities for teachers in the development of competencies in the field of technology, it helps to change the educational, professional activities and life of society as a whole for the better. Quick registration by filling out the registration form is required to get access to the full capabilities of this platform. Packet Tracer - a powerful network modeling tool created by Cisco, will help the user apply knowledge and skills in a real-world setting, for it provides hands-on experience building simple and complex networks involving a variety of devices aside form simple mapping with the use of just routers and switches, as well as it promotes the creation of interconnected solutions for smart cities, homes and businesses. Using Packet Tracer is possible as a learning environment for lessons, courses, distance learning, training, work planning or just for fun.

Adobe Education Exchange -is a free learning and community platform that offers master classes, lessons and resources developed by educators for educators of GSEIs and HEIs and aimed at developing and improving the professional competence of modern teachers, including CS specialists. It contains teacher training courses, as well as educational multilevel resources from different subject areas.

Makey - this online resource contains an instruction center for teachers, which offers a library of ready-made interdisciplinary projects grouped by categories, among which the user can find: coding, technology, robotics, etc. This platform is useful not only for computer science teachers in order to develop their professional competence, but also for subject teachers of the environmental sciences and math. Makey also allows to get 
acquainted with the largest collection of step-by-step creation of STEM-projects.

\section{Conclusions and research perspectives.}

Thus, psychological, pedagogical, methodical literature on the issues of development of professional competence of the modern teacher of computer science was analyzed during the research; the peculiarities of the development of corresponding competence within the framework of informal education were highlighted; structure and main directions of informal education in Ukraine are described and outlined.

Analysis of foreign and domestic experience in the development of professional competence of computer science teachers and different types of education made it possible to identify informal education as an alternative to formal education in lifelong learning and, conclusively, as a part of continuous professional development and gradual growth of pedagogical skills of CS educators.

Processing of the legal framework for the functioning of informal education and its impact on the development of professional competence of computer science teachers showed that the state is currently taking a number of measures to ensure continuous development of professional competence of modern educators, which should include such areas and the use of the latest technologies in the learning process of students. Some of its aspects are defined and the ways of organizing the process of development of professional competence of teachers in the conditions of non-formal education are described.

Further research can be aimed at reviewing the results of approbation of the presented materials in real conditions and substantiation as well as development of plans and programs for the amplification of professional competence of teachers in the conditions of informal education.

\section{REFERENCES (Translated \& transliterated)}

1. Balovsiak, N.V.

Formuvannia kompetentnosti ekonomista $v$ protsesi profesiinoi pidhotovky [Formation of information competence of the future economist in the process of professional training]. Candidate's thesis. Kyiv: NAES of Ukraine [in Ukrainian].

2. Byrka, M.F. (2015). Teoriia $i$ praktyka profesiinoho rozvytku vchyteliv pryrodnycho-matematychnykh

dystsyplin u pisliadyplomnii osviti [Theory and practice of professional development of teachers of natural and mathematical disciplines in postgraduate education: monograph]. Chernivtsi: Tekhnodruk [in Ukrainian].

3. Drozd, T.M. (2017). Rozvytok komunikatyvnoi kompetentnosti vchyteliv filolohichnykh spetsialnostei u systemi pisliadyplomnoi osvity [Development of communicative competence of teachers of philological specialties in the system of postgraduate education]. Candidate's thesis. Vinnytsia: Vinnytsia Mykhailo Kotsyubynsky State Pedagogical University [in Ukrainian].

4. Elkin, M.V. (2005). Formuvannia profesiinoi kompetentnosti maibutnoho vchytelia heohrafii zasobamy proektnoi diialnosti [Formation of professional competence of the future teacher of geography by means of project activityl. Candidate's thesis. Kyiv: Central Institute of Postgraduate Education NAES of Ukraine [in Ukrainian].

5. Zhaldak, M.I., Ramskyi, Yu.S., \&Rafalska, M.V. (2009). Model systemy sotsialno-profesiinykh kompetentnostei vchytelia informatyky [Model of the system of socio-professional competencies of a computer science teacher]. Naukovyi chasopys Natsionalnoho pedahohichnoho universytetu imeni M.P. Drahomanova. Seriia 2. Kompiuterno-oriientovani systemy navchannia - Scientific journal of the National Pedagogical University 
named after MP Drahomanov. Series 2. Computer-based learning systems, 7, 3$10 . \quad$ Retrieved from https://sj.npu.edu.ua/index.php/kosn /article/view/409 (data zvernennia 05.04.2021) [in Ukrainian].

6. Kovalenko, L.V. (2017). Rozvytok profesiinoi kompetentnosti vchytelia ukrainskoi movy ta literatury $v$ systemi pisliadyplomnoi osvity: metodychnyi posibnyk [Development of professional competence of a teacher of Ukrainian language and literature in the system of postgraduate education: methodical manual]. Sumy: Niko [in Ukrainian].

7. Kozyryna, O.A.

Kompetentnost

(2004).

sovremennoho

uchytelia: sovremennaia problema opredelenyia poniatyia [Competence of a modern teacher: a modern problem of concept definition]. Standarty $y$ monytorynh $v$ obrazovanyy - Standards and monitoring in education, 2. Retrieved from http://www.enpuir.npu.edu.ua/bitstre am/123456789/4712/1/Nevmerzhytsk a.pdf [in Russian].

8. Kryvosheieva, O.I.

Formuvannia profesiinoi etyky maistriv vyrobnychoho navchannia profesiinotekhnichnykh navchalnykh zakladiv [Formation of professional ethics of masters of industrial training of vocational schools]. Candidate's thesis. Vinnytsia: Vinnytsia Mykhailo Kotsyubynsky State Pedagogical University [in Ukrainian]. Retrieved from

https://dspace.vspu.edu.ua/bitstream /handle/123456789/924/Kryvosheieva .pdf? sequence $=1 \&$ is Allowed $=y \quad$ [in Ukrainian].

9. Ovcharuk, O.

(2005). Kompetentnosti yak kliuch do onovlennia zmistu osvity. Osvita v konteksti stratehichnykh zavdan rozvytku Ukrainy [Competences as a key to updating the content of education. Education in the context of strategic objectives of Ukraine's development]. Dyrektor shkoly Ukraina: naukovo-metodychnyi zhurnal - Director of the school Ukraine: scientific and methodical magazine, 3-4. Retrieved from

https://ru.osvita.ua/school/method/3 81/ [in Ukrainian].

10. Zakon Ukrainy Pro Natsionalnu prohramu informatyzatsii vid 4 liut. 1998 roku N 27-28 [Law of Ukraine On the National Informatization Program from February 4 1998, N 27-28]. (1998, February 4). Retrieved from http: //ru.osvita.ua/legislation/law/31 63/ [in Ukrainian].

11. Zakon Ukrainy Pro osvitu vid 5 ver. 2017 roku № 38-39 [Of the Law of Ukraine On Education from September 5 2017, № 38-39]. (2017, September 5). Retrieved from https://zakon.rada.gov.ua/laws/show/ 2145-19\#Text [in Ukrainian].

12. Pro skhvalennia Kontseptsii rozvytku tsyfrovykh kompetentnostei ta zatverdzhennia planu zakhodiv $z$ yii realizatsii: rozporiadzhennia № 167-r. [On approval of the Concept of development of digital competencies and approval of the action plan for its implementation: order № 167-r]. (2012, March 03). M-vo tsyfrovoi transformatsii. Retrieved from https:/ / zakon.rada.gov.ua/laws/show/ 167-2021-\%D1\%80\#Text

[in Ukrainian].

13. Rozporiadzhennia Pro skhvalennia Kontseptsii rozvytku tsyfrovykh kompetentnostei ta zatverdzhennia planu zakhodiv $z$ yii realizatsii vid 03 ber. 2021 roku № 167 $r$ [Order on approval of the Concept for the development of digital competencies and approval of the action plan for its implementation from March 3 2021, № 167-r]. (2021, March 3). M-vo tsyfrovoi transformatsii. Retrieved from https:/ / zakon.rada.gov.ua/laws/show/ 167-2021-\%D1\%80\#Text

Ukrainian].

14. Sikora, Ya.B.

(2008). Formuvannia profesiinoi kompetentnosti maibutnikh vchyteliv informatyky $\mathrm{v}$ kursi "Metodyky navchannia informatyky" [Formation of 
professional competence of future teachers of computer science in the course "Methods of teaching computer science"]. Mizhnarodnoi naukovopraktychnoi konferentsii "Teoretykometodolohichni zasady pidhotovky pedahohichnykh kadriv u polietnichnomu rehioni" - International scientific-practical conference "Theoretical and methodological principles of teacher training in a polyethnic region". Retrieved from http://eprints.zu.edu.ua/19815/1/\%D 0\%B0\%D0\%B2\%D1\%82\%D0\%BE\%D1 \%80\%D0\%B5\%D1\%84\%D0\%B5\%D1\%8 0\%D0\%B0\%D1\%82.pdf [in Ukrainian].

15. Sysoieva, S.O. (2012). Problemy neperervnoi profesiinoi osvity: tezaurus naukovoho doslidzhennia: nauk. vydannia. [Problems of continuing professional education: thesaurus of scientific research: science. edition]. Kyiv: Vydavnychyi Dim "EKMO" [in Ukrainian].

16. Khutorskoi, A. (2003). Kliuchevye kompetentnosty kak komponent lychnostno oryentyrovannoi systemy obrazovanyia [Key competencies as a component of a personality-oriented education system]. Narodnoe obrazovanye - Public education, 2. Retrieved from https://scholar.google.ru/citations?use $\mathrm{r}=$ NhfQflOAAAAJ\&hl=ru [in Russian].

17. Shyshko, A.V.

Formuvannia

(2010). pedahohichnoi vykladacha inozemnoi movy u protsesi mahisterskoi pidhotovky [Formation of pedagogical competence of the future foreign language teacher in the process of master's preparation]. Candidate's thesis. Kyiv [in Ukrainian].

18. Education for All: Meeting Our Collective Commitments. (2000). The Dakar Framework for Action: UNESCO. Retrieved from: http://unesdoc.unesco.org/images/00 12/001284/128463e.pdf [in English].

19. UNESCO Policy guidelines for mobile learning. (2013). United Nations Educational, Scientific and Cultural Organization, 7, France [in English].

20. Hicks, K. (2015). Top Education Technology Trends. Edudemic, May 13, $2015 . \quad$ Retrieved from http:/ /www.edudemic.com/educationtrends-keep-tech-front-center/ in English] 